\title{
O grito: a reiteração do poder em Fogo morto de José Lins do Rego.
}

\author{
João Carlos Guedes da Fonseca ${ }^{1}$
}

\section{Resumo:}

O grito é o protagonista de Fogo morto, décimo romance de José Lins do Rego. Sob ele ou ao seu redor, a vida do engenho Santa Fé, palco em que se encena - as histórias de mestre José Amaro, Coronel Lula de Holanda e Vitorino Carneiro Cunha, - impregna-se de uma fatalidade própria àqueles que, imóveis e débeis. O motivo da segregação é também o ânimo de uma estranha forma de comunhão. A junção revela os impasses de um mundo fragmentado que, por uma estranha dialética, teima em resistir contra o esfacelamento de uma improvável, mas sempre almejada reviravolta na ordem dos acontecimentos.

Palavras-chaves: José Lins do Rego - Ciclo da cana-de-açúcar - Modernismo - Regionalismo

\begin{abstract}
:
The scream is the protagonist of Fogo Morto, tenth novel by José Lins do Rego. Under him or around him, the life in the Engenho Santa Fé, stage where take place the stories of master José Amaro, Colonel Lula de Holanda and Vitorino Carneiro Cunha, is impregnated with a fate characteristic of those who, motionless and weak, watch the approaching of the end, without being able to do a thing. The reason of the segregation is also the spirit of a community feeling. The junction revelates the impasses of a fragmented world that, by a strange dialectic, insist on resisting against the destruction of an unlike, but always longed for, about turn in the sequence of events.
\end{abstract}

Keywords: José Lins do Rego - sugarcane cycle - modernism - regionalism

\footnotetext{
${ }^{1}$ Pesquisador com Pós-doutrado pelo Instituto de Biociências, Letras, Ciências e Exatas de São José do Rio Preto/UNESP. Autor, entre outros artigos, de "O mercado do gozo" in: Revista Vintém 5, São Paulo, 2004 e "Considerações sobre a constituição do foco narrativo, em O ermitão do Muquém, de Bernardo Guimarães." In: CD-Rom do VIII congresso internacional ABRALIC 2002 - UFMG. 
A rua, a casa e a brisa da manhã: Amaro e a síntese antecipada.

Originalmente, violência - da mesma raiz de Violenter, Violare, Violatus compartilha o campo semântico da profanação: atentar contra a integridade de algo ou de alguém com ímpeto cruel, rompimento das fronteiras que separam os homens e as coisas, sair de si mesmo rumo ao outro com intenção de destruí-lo. A violação uniformiza as diferenças à medida que agride o diverso para transformá-lo em extensão do agente da devastação. Essa é a essência da cadeia regulativa de idéias a qual personagens de Fogo morto de José Lins do Rego está sujeita. Sentem o mundo que as cerca como espaço da violência.

$$
* * * * *
$$

- Bom dia, mestre Zé - foi dizendo o pintor Laurentino a um velho de aparência doentia, de olhos amarelos, de barba crescida.

- Está de passagem, seu Laurentino?

- Vou ao Santa Rosa. O coronel mandou me chamar para um serviço de pintura na casagrande. Vai casar filha.

O mestre José Amaro, seleiro dos velhos tempos, trabalhava na porta de casa com a fresca da manhã de maio agitando as folhas da pitombeira que sombreava a sua casa de taipa de telheiro sujo. Lá para dentro estava a família. Sentia-se cheiro de panela no fogo, chiado do toicinho no braseiro que enchia a sala de fumaça.

- Vai trabalhar para o velho José Paulino? É bom homem, mas eu lhe digo: estas mãos que o senhor vê nunca cortaram sola para ele. Tem a sua riqueza, e fique com ela. Não sou criado de ninguém. Gritou comigo, não vai.

- Grita, mas é bom homem, mestre Zé.

- Eu sei. A bondade dele não me enche a barriga. Trabalho para homem que me respeite. Não sou um traste qualquer. Conheço estes senhores de engenho da Ribeira como a palma da minha mão. Está aí, o seu Álvaro do Aurora que custa a pagar. É duro de roer, mas gosto daquele homem. Não tem este negócio de grito, fala manso. É homem de trato. Isto de não pagar não está na vontade dele. Também aquele Aurora não ajuda a ninguém. ${ }^{2}$

\footnotetext{
${ }^{2}$ REGO, José Lins. Fogo morto. Rio de Janeiro: José Olympio, 1993, p. 5.

Mediações - Revista de Ciências Sociais, Londrina, v. 10, n.1, p. 87-104, jan.-jun. 2005 ISSN 1414-0543 O GRITO: A REITERAÇÃO DO PODER EM FOGO MORTO DE JOSÉ LINS DO REGO. João Carlos Guedes da Fonseca
} 
A cena inaugural de Fogo morto abre-se com duas cisões, uma espacial e outra temporal. A casa de taipa do mestre Amaro, esfumaçada, contrapõe-se ao campo aberto dos canaviais abraçados pela brisa da manhã de maio. Varejando-as, em silêncio, um passado misterioso identificado pela locução velhos tempos é o terreno movediço de onde brotam as raízes do seleiro e de sua família. À rua, os senhores de engenho, a cidade, o cangaceiro Antônio Silvino e tenente Maurício. Sob o telheiro sujo, Marta e Sinhá. Do diálogo entre essas dimensões nasce em grande parte o sentido do drama particular de Amaro e geral da obra de José Lins do Rego.

Há um efeito cascata percorrendo as cercanias do Santa Fé que obnubila os sentidos de seus moradores. Projetam saídas falsas para os problemas que se lhes anunciam em virtude da experiência brutal da violência. $\mathrm{O}$ ataque contra José Paulino, a referência ao não pagamento do soldo pelas suas selas e a esperança depositada em Antônio Silvino são, em mestre Amaro, conseqüências da interiorização das forças objetivas da sociedade nas cercanias da pessoa. De um lado, age como se fosse dono de seu destino quando recusa prestar seus serviços ao coronel Santa Rosa. De outro, percebe-se impotente em face da legislação misteriosa que o impede de receber pelo seu ofício. Oscila entre essas duas realidades, aparentemente antagônicas, que nele convivem amplamente. $\mathrm{O}$ olhar do mestre sobre o mundo obedece a essa estranha conformação. Quando mercadoria reage contra José Paulino. Quando não, aceita Álvaro da Aurora e deposita suas esperanças no cangaço, casagrande camuflada pelo couro cru do sertão.

A oposição de Amaro com Laurentino é, nesse sentido, farsa. Não há grande diferença entre pintar o Santa Rosa e "vender" selas. Ambos o fazem de graça. Faz-se a dissensão, isso sim, pelo modo de reagir contra esse estado. A língua sem arreios do seleiro torna-se o grito de José Paulino em sinal invertido. No vai e vem do pêndulo que o constitui, Amaro teima em ser aquilo que de fato não é: homem livre. A liberdade para ele é a escolha de quem pode comprar-lhe as selas que produz. Entretanto, não há mercado às 
margens do Paraíba de modo que nada nem ninguém se torna, plenamente mercadoria. Logo, Álvaro da Aurora não pode ser penalizado por não lhe pagar: Isto de não pagar não está na vontade dele. Condena com sua recusa, aquilo que no limite de sua condição deseja para si: alguém que possa protegê-lo num eventual júri. Foi assim com seu pai, deveria ser assim com ele. Reconhece apenas o poder brutalizado, porque somente essa forma de sociabilidade lhe é sensível. Por isso, resvala no bando de Antônio Silvino, homem mais poderoso que José Paulino, mais forte que qualquer senhor de engenho da Ribeira, sentença repetida a exaustão pela boca do velho seleiro.

Ninguém é responsável direto pela coerção, pelo não pagamento do soldo. O seleiro, malgrado suas críticas, reconhece a bondade de José Paulino e isenta Álvaro da Aurora de não ressarcí-lo pelas selas que produziu. O seu encontro com Laurentino, ainda pela mão hábil do narrador que invade como o grito de José Paulino todos os recantos daquele mundo é envolvido pela natureza mesma. Sob a sombra da pitombeira, abraçados pela brisa da manhã de maio, os dois homens iniciam sua conversa. A sugestão é poderosa. O desenrolar dos acontecimentos, isto é, a tentativa de Amaro enfrentar o coronel do Santa Rosa e a explícita conivência de Laurentino com o senhor de engenho, segue a ordem regular das coisas. Uma interação anuncia-se, não por acaso, entre homem e mundo. A voz do vento agitando a folhagem mescla-se e confunde-se com as palavras ásperas do seleiro e o laconismo das respostas dadas pelo pintor. Os movimentos com suas devidas nuances integram-se numa mesma lógica. Será comum em Fogo morto essa harmonia. Há por trás dela, o sentimento de que a violência é natural. O conjunto de fenômenos físicos e sociais são fiéis à mesma legislação. Como veremos, até mesmo o modo peculiar do narrador interferir na narrativa, parece seguir o mesmo caminho.

Antonio Candido na Formação da Literatura Brasileira une o regionalismo romântico ao romance nordestino dos anos 30 a partir de uma compreensão do complexo de 
problemas sociais da região. ${ }^{3}$ A perda da hegemonia político-econômica tornou-se para os romancistas do Nordeste faca de dois gumes: de um lado, a exaltação à terra; de outro, a aproximação com o substrato mais baixo da sociedade revelou-se forte material de crítica. Essa polaridade, entre muitas outras, também é tensão na obra de José Lins do Rego. A exuberância, que, em outros autores, extasiava os olhos pela beleza desmedida da natureza, assume outra conotação nos romances do autor de Fogo morto. Desde Menino de engenho, as forças da terra são sempre desmedidas em violência. Apresenta-se na cheia, na seca, na chuva torrencial, no sol escaldante. Com elas trava-se luta renhida pela sobrevivência. Em paralelo, o grito da natureza tem o ímpeto dos gritos dos coronéis. Na história do Santa Fé essa disposição é revista por José Lins do Rego, e aquilo que fora violência apazigua-se em comunhão surda com os homens e a sociedade. O resultado é homogeneização das vozes da narrativa em tom único. A brisa da manhã de maio que sobrevoa o encontro de Laurentino e Amaro faz-se consentimento e não contraste às palavras ressecadas da bagaceira.

Para ilustrar esse descompasso, servimo-nos de uma galeria inesgotável de imagens e cenas espalhadas em abundância na obra de José Lins do Rego: a famosa cheia de Menino de engenho contra a qual não há adversário; a vingança do Paraíba em Usina, cuja força desproporcional expulsa Juca da sede da Bom Jesus, metaforizando uma redenção da bagaceira face a usura dos poderosos; o sol perene de Riacho doce e Pedra bonita que atordoa os sentidos e castiga a terra e seus moradores. É claro que a natureza se encontra em posição reagente contra a violência que organiza e submete a vida à penúria. No entanto, a inversão não isenta essa mesma natureza de uma cumplicidade com o grito de mando à medida que ambos falam a mesma língua. Essa parece ser a reviravolta de Fogo morto.

O colorido pitoresco tão forte nos romances de Lins do Rego já nasce na primeira obra do romancista em dissidência com a tradição literária nordestina. A experiência

\footnotetext{
${ }^{3}$ CANDIDO, Antonio. Formação da literatura brasileira. São Paulo V. 2 : Martins, pp. 298-303. 
acumulada pelos seus antecessores é, desde o livro de estréia, recusada pela superação de sua polaridade central. Franklin Távora, Joaquim Belo e Mario Sette, e tantos, faz-se presente na obra de José Lins do Rego por negativa. Daí, a impressão de tudo começar em marco zero na literatura do escritor paraibano. O esquecido, mas agudo Olívio Montenegro é certeiro quando afirma: e contudo não se pode dizer que seja um grande escritor, no sentido rigoroso da palavra, José Lins do Rego; é mais uma natureza. O escritor é o homem para quem o estilo é a realidade suprema - ele medita, compõe, escolhe, analisa, faz e refaz a idéia dentro de si; a expressão é que tudo comanda, subordina a vida à forma. Luta para vencer a natureza. Em José Lins do Rego o romance é como se fosse obra mais do instinto do que da reflexão. ${ }^{4}$

Se a natureza é grito, as forças objetivas da sociedade também o são. Em $A$ presença do Nordeste na literatura brasileira José Lins do Rego soma esforços à tentativa de Candido de rastrear por qual caminho se deu a acumulação no Regionalismo. Centra atenção no cangaço, em Cabeleira, Antônio Silvino e Lampião. Em ambivalência contínua, compreende-os como única possibilidade de enfrentamento contra as forças coercitivas do sertão e como parte da engrenagem de um mundo alheio ao Estado de direito.

Mestre Amaro estabelece sua esperança nesse interregno, o equívoco de acreditar sua vingança contra os senhores de engenho no cangaço é dado pela conformação social à qual pertence. Por isso, o seleiro é denúncia. Não se trata de ideologia no plano estrito, mas sim de interiorizar na vida mesma as fraturas de um universo, cuja organização de base coage e o impede de enfrentar diretamente a cadeia de sentidos que iguala a casa-grande ao cangaço; a força policial à natureza, enquanto marcas do poder brutalizado. Nas palavras de José Lins do Rego: a história do cangaço, no nordeste brasileiro, está intimamente ligada a história social do patriarcalismo, a vida de uma região dominada pelo mandonismo do

\footnotetext{
${ }^{4}$ MONTENEGRO, Olívio. O romance brasileiro. Rio de Janeiro: José Olympio, 1953, pp. 172-3. 
senhor de terras e de homens, como se fossem barões dos feudos (...) Nem o Estado seria capaz de enfrentar o chefe que no sertão era mais que o Estado. ${ }^{5}$

O modo pelo qual José Lins do Rego trama as relações do cangaço com o patriarcalismo sugere o tempo histórico como estagnado numa conformação material, cuja origem é o surgimento do Brasil colônia. Afinal, o patriarcado é fronteira primeira das terras na América portuguesa; movimento de repetição, analisado e discutido em verticalidade pela literatura das nossas ciências sociais. Por tratar esse de ponto pacífico entre as mais diversas correntes críticas, supõem-se que os coronéis, cangaceiros e agregados de Fogo morto são personagens eternizados no tempo e no espaço. Estaríamos diante de um ciclo vicioso, sem futuro, sem saída para seus impasses de base. Não haveria progresso, isto é, avanços reais na articulação do passado com o presente. Mesclar-se-iam num ponto único e exclusivo de eterno retorno, reproduzindo-se ad infinitum. Avançar nessa discussão de enorme bibliografia é tarefa arriscada para a qual um trabalho de crítica literária parece não estar habilitado. Entretanto, a obra de Lins do Rego, em especial Fogo morto, exige de nós esse disparate. Sobretudo quando os velhos tempos de mestre Amaro reivindica decifração.

Com os velhos tempos revela-se a posição do narrador de Fogo morto, e principalmente, a convergência da ficção mesma com o material histórico sobre o qual realiza a representação. O narrador oscila sem cerimônia do passado ao presente, do objetivo ao subjetivo para alinhavar as origens de Amaro ao tecido roto de sua atual condição. A indefinição faz sombra à procedência do seleiro. Não há referência a um marco temporal preciso. A única informação encontra-se nos adjetivos atribuídos a ele pelo narrador: velho, de aparência doentia, de olhos amarelos, de barba crescida. Dois grupos surgem desse conjunto: ora o campo semântico do enunciado se circunscreve a velhice, ora

\footnotetext{
${ }^{5}$ REGO, José Lins do. A presença do nordeste na literatura brasileira. Rio de Janeiro: Ministério da Educação e Cultura, 1957, p. 31

Mediações - Revista de Ciências Sociais, Londrina, v. 10, n.1, p. 87-104, jan.-jun. 2005 ISSN 1414-0543 O GRITO: A REITERAÇÃO DO PODER EM FOGO MORTO DE JOSÉ LINS DO REGO. João Carlos Guedes da Fonseca
} 
resvala na contingência da doença. No diálogo entre eles, inicia-se o processo de separação de Amaro e Laurentino que irá culminar em desavença com o personagem José Paulino. Há uma sobreposição de informações na primeira linhagem de imagens. Velho revela a consumação de um percurso pelo qual as experiências acumuladas se transformaram em marcas aparentes. Por elas é possível abrir a trilha rumo a vida que se esconde para além dos sulcos gravados na fronte. A existência de uma história pregressa de mestre Amaro é o que nos indica esse adjetivo. Por sua vez, a locução de barba crescida torna manifesto que o passado está patente à vista. O trabalho dos anos urdiu os fios em trama que se revela franca para o leitor.

No outro pólo, de aparência doentia e de olhos amarelos qualificam a vida, a esperança minada pelo trabalho do tempo, a abrir-se em seqüelas e fraturas. Obstáculos enormes, marca da insígnia do fracasso. Sem nada ser alcançado. E o narrador transita livremente no passado de lamúrias. Conhece os velhos tempos do seleiro. A sobreposição das imagens revela a sua onisciência, o saber de todo um percurso. Uma história que será exposta ao leitor nos espaços abertos pelos fios de barba crescida. Ele conduz a ação narrativa com plena consciência do acontecido. O passado irrompe a membrana do presente e estabelece um diálogo entre a tradição e a urgência da vida. É preciso identificar os limites desse tempo pregresso de onde surge o seleiro do Santa Fé. Do que ele resulta? Há pelo menos três dimensões. A primeira, a própria experiência da personagem nos entraves de sua existência íntima. Encontra-se no círculo de sua família, cujo centro é o crime de morte cometido por seu pai. Do assassinato saiu o veredicto que o prendeu às terras de Lula de Holanda. Existe ainda a aproximação cerrada com imagens da cena inaugural de Fogo morto. Ela apresenta a verdadeira dimensão dos domínios desse narrador. Evade-se além das fronteiras da história pessoal de Amaro e encontra refugo na verdadeira verve da literatura de José Lins do Rego. Os velhos tempos - identifica tanto os limites pessoais do mestre, quanto a divisa de um grande projeto literário, que ganha sentido a luz de Fogo

\footnotetext{
Mediações - Revista de Ciências Sociais, Londrina, v. 10, n.1, p. 87-104, jan.-jun. 2005 ISSN 1414-0543 O GRITO: A REITERAÇÃO DO PODER EM FOGO MORTO DE JOSÉ LINS DO REGO. João Carlos Guedes da Fonseca
} 
morto. Por fim, a compreensão da história mesma como bloco hegemônico de sucessivos fracassos que, como represa sólida, impede o avanço da torrente. O narrador, ao se fazer onisciente, oscila entre três pólos, indistintamente. Todos compartilham os adjetivos atribuídos ao mestre; todos acumulam insucessos em vida: este circunscrito à figura de um homem, aquele a sombra de nove romances, o outro ao estranho sentimento de que a cadeia da qual se precisa fugir não possui cadeado à vista.

O pai de mestre Amaro, seleiro de renome na corte, cometera crime de morte, o que o obrigou a fugir de Itabaiana e pedir proteção ao velho capitão Tomás, fundador do engenho Santa Fé e sogro de Lula de Holanda. Não se sabe nada sobre o assassinato, apenas o fato surge como motivo de desgraça do seleiro. Pela comparação imediata com outros personagens do romance, principalmente Alípio, crê-se que o pai de Amaro teve resguardo de poderosos no júri. O estado de direito está nas mãos de quem detém o poder de mando. Se agraciado o criminoso pela estima dos poderosos, liberdade: bicho homem, esse Alípio. Avalie que quase menino se espalhou na feira do Ingá que foi aquela desgraça. Gosto de homem assim. Ele fora com o pai vender milho verde na vila e o cabo do destacamento achou de desfazer do velho. Foi aquela desgraça. Alípio se fez na faca, espalhou a feira. O cabo ficou para um canto de bofe de fora, e um soldado que se metera a besta não ficou para contar a história. Foi no Júri. Encontrou homem para livrar ele. Se fosse aqui no Santa Fé, morria de podre na cadeia. Nem é bom falar.

A história de Alípio recoloca os valores em jogo, esclarecendo a origem da valentia anteriormente anunciada por Amaro. A defesa do pai perante os desaforos da milícia, o crime de morte, o júri, a comparação com o Santa Fé. O processo de identificação do seleiro com o matuto é mediado pela sua coragem de enfrentar o poder. Vê-se, como ele, reforçando as expectativas criadas no início da conversa com Laurentino. Será Amaro o homem que enfrentará os senhores de engenho da Ribeira? Alípio agiu como homem porque estava resguardado. Ambos reexaminam as relações de poder a que estão 
submetidos os homens da bagaceira. Por isso, o júri e indiretamente Lula de Holanda aparecem como centro da história de Alípio. A proteção obtida pelo matuto tanto o salva da cadeia quanto revela a impossibilidade de que um Estado de direito consiga se contrapor às leis do mando. Não há poder constituído que esteja isento das influências dos senhores de engenho. Para sobreviver naquelas veredas é preciso o apadrinhamento de um poderoso qualquer, caso contrário não há salvação contra a violência. Tal apresentação apenas confirma as mazelas do seleiro. Afinal, Lula é um decadente, um fraco diante de seus pares. Paradoxalmente, Amaro parece necessitar daquilo que acusou em José Paulino, isto é, os gritos. Se eles corroboram à servidão eles também são marcas de uma proteção de que a bagaceira não pode abrir mão.

A liberdade de Alípio e conseqüentemente do pai de Amaro é diferente daquela de que o seleiro se serviu para enfrentar José Paulino. Essa contradição dialoga em grau agudo com a conformação particular da história brasileira. Livre, nos canaviais de José Lins do Rego, é aquele que, submisso às vontades dos grandes proprietários, age segundo os desígnios da casa-grande. Uma liberdade assistida. Não é por isso, o liberalismo econômico para qual a forma mercadoria alça o grau de princípio organizador. Mestre Amaro anima-se em outro diapasão, mostra-se alienado pela impossibilidade de ser mercadoria pela possibilidade de não sê-la. Onde ele se encontra?

A tensão provocada no cerceamento do olhar se agrava na sugestão de que Fogo morto segue a mesma ordem dos acontecimentos do primeiro romance do Ciclo da canade-açúcar, Menino de engenho. Isso porque o motivo da ida de Laurentino para o Santa Rosa é o casamento de Maria, narrado no livro de estréia de José Lins do Rego. Ele quebra o fluxo contínuo dos seus cinco primeiros livros e lança novamente o leitor na formação e construção das primeiras impressões de Carlinhos. Em sentido estrito, a principal base material para o desenvolvimento da história do Santa Rosa. O passado, àquela época, circunscrevia-se à infância do neto de José Paulino.

Mediações - Revista de Ciências Sociais, Londrina, v. 10, n.1, p. 87-104, jan.-jun. 2005 ISSN 1414-0543 O GRITO: A REITERAÇÃO DO PODER EM FOGO MORTO DE JOSÉ LINS DO REGO. 
Mestre Amaro, nesse sentido, parece não falar com Laurentino, mas impõe-se sobre o próprio Ciclo, refaz o curso e apara as arestas da narrativa. Desde Menino de engenho José Paulino se diferencia dos demais senhores de engenho. Se há uma imagem recorrente do poderoso coronel é a que admite a bondade, não obstante seus gritos.

Carlos de Melo é o primeiro a sentenciar esse juízo sobre seu avô: parece que aquelas palavras feias na boca do velho José Paulino não quisessem dizer coisa nenhuma. Muitos vinham arranjar carros do engenho para fazer mudanças e alguns dar contas de suas meações com o senhor ou pagar o foro do ano. A todos o meu avô ia dando uma resposta ou passando uma descompostura, mas cedendo sempre no que eles pediam. ${ }^{6}$ Até mesmo Ricardo, primeira tentativa de deslocar o ponto de vista da casa-grande para a bagaceira compartilha dessa opinião: mas aumentou dez mil-réis. Porém a raiva a seu Alexandre permaneceu. Era a primeira pessoa por quem tinha repulsa, mesmo ódio. No entanto o patrão o tratava bem, sem gritos, sem aborrecimentos. Também não dava por onde. Vivia com os outros aos berros. Os homens da padaria até o patrício viviam com o patrão pelas goelas. Ninguém levasse pão para casa que ele visse. Chamava de ladrão a todo mundo. Não era o 'ladrão' da boca do velho Zé Paulino. Era um ladrão que feria os outros com vontade de ofender (grifo meu)". 7 As insatisfações de Ricardo eram de outra ordem, revoltava-se contra a miséria de sua família, contra um futuro que não conseguiriam burlar. Ficariam sempre, como ele mesmo ficou, a mercê das ordens de outrem, confinados na pobreza, mergulhados na resignação. O alvo portanto, não é o poderoso dono do Santa Rosa. Ele resiste, protegido pela sua "bondade", às revelações do moleque.

A conversa de mestre Amaro com Laurentino é, nesse sentido, avassaladora, pois lança José Paulino na berlinda. Contra ele, o seleiro levanta a voz. Todas as justificativas que mantiveram o coronel separado de seus pares são questionadas pelo seleiro. Os gritos

\footnotetext{
${ }^{6}$ REGO José Lins do. Menino de engenho. Rio de janeiro: José Olympio, 1995, pp 41-42. ${ }^{7}$ REGO José Lins do. O moleque Ricardo. Rio de janeiro: José Olympio, 1993, pp. 21-22. 
indicam menosprezo, a sua bondade não enche barriga e, por fim, ele é mais um senhor de engenho. As imagens indicam, por parte do escritor, uma reflexão profunda sobre a primeira parte do Ciclo da cana-de-açúcar, como se todos os seus romances iniciais estivessem em julgamento. Não existe mais a possibilidade de salvaguardar qualquer um dos poderosos daquela região, e essa é a mensagem implícita na cena inaugural de Fogo morto.

Se o olhar do escritor oscilou da casa-grande para as cercanias do engenho é verdade também que José Paulino se preservou sem arranhões desse deslocamento do ponto de vista. Até mesmo nos seus últimos dias, quando se encontrava arrebatado pela senilidade, não lhe negavam a soberania de outros tempos: não. Não podia me envergonhar do meu avô. Mário Santos saberia vê-lo no seu tamanho natural. Se o conhecesse mais moço, mais viril, haveria de sentir orgulho daquela energia vigorosa para o trabalho, daquela vida que se fizera ao sol e à chuva (...). Podia escarrar pelo chão, andar de palito na boca, molhar o beiju no chá, dar os seus gritos. Nada disto degradaria a sua vida. A terra que cultivou que falasse do dono infatigável que a possuiu (...) O neto é que era uma besta, um preguiça. Inútil, sem a coragem e vigor do sangue que lhe corria pelas veias. ${ }^{8}$

De um lado, menos objetivo, o Ciclo da cana-de-açúcar reaparece em Fogo morto, como mostra o resgate da imagem de José Paulino; de outro lado, mais claramente definido pelas circunstâncias da ação, um movimento que não respeita a herança deixada pelos romances anteriores busca erguer os alicerces de um novo enquadramento narrativo. A tarefa do narrador é encontrar o equilíbrio entre esses vetores. É preciso deixar que os personagens falem.

Duas forças, de naturezas distintas, convergem na recusa do mestre. A primeira evoca uma tradição inteira de onde surgiu e para a qual se volta. A segunda relaciona-se com o próprio instante de sua aparição, fustigada na urgência do momento presente,

${ }^{8}$ REGO, José Lins do. Bangüê. Rio de janeiro: José Olympio, 1993. p..26.

Mediações - Revista de Ciências Sociais, Londrina, v. 10, n.1, p. 87-104, jan.-jun. 2005 ISSN 1414-0543 O GRITO: A REITERAÇÃO DO PODER EM FOGO MORTO DE JOSÉ LINS DO REGO. João Carlos Guedes da Fonseca 
condicionada à voz daquele que a invoca. Somente no diálogo entre elas, a história do Santa Fé é possível. Por isso, a publicação de Fogo morto, em 1943, surpreendeu o cenário literário brasileiro, seja por ressuscitar personagens e espaços que compuseram a primeira parte do Ciclo, dando-lhes novos significados, seja porque seu enquadramento formal reorganizou conflitos narrativos, remodelando-os a uma nova ordem de acontecimentos. Àquela época, via-se na decadência um processo, um fluxo da integridade à destruição completa: em primeiro lugar, resguardava-se o engenho contra o inimigo que avançava incógnito pelo interior da Paraíba, substituindo a antiga moenda por chaminés enormes (Menino de engenho); depois, a educação do herdeiro de José Paulino na escola do Pilar transformar-se-ia no centro das atenções do escritor, na revelação dos percalços da aprendizagem de um futuro senhor de engenho, embora desgarrado de suas origens (Doidinho); em seguida, a morte de José Paulino, e a ascensão de Carlos de Melo à única voz de comando no engenho resulta em seu fracasso (Bangüê); por último, "a história do Santa Rosa arrancado de suas bases, espatifado, com máquinas de fábrica, com ferramentas enormes, com moendas gigantes, devorando a cana madura que suas terras fizeram acamar pelas várzeas" (Usina). ${ }^{9}$ Concomitante a esse movimento, outro ampliava o campo de visão do escritor: a ação às margens da casa-grande, a miséria da bagaceira. Até mesmo um livro, aparentemente dissociado do Ciclo, uma vez que sua ação transcorria no espaço urbano de Recife, foi publicado. O moleque Ricardo representa o instante mais agudo desse deslocamento. Um narrador em terceira pessoa afirma-se sobre o narrador/personagem dos três primeiros livros de José Lins do Rego. A partir dele, a compreensão do mundo não seria exclusiva aos senhores de engenho. O desdobramento da narrativa segue dupla orientação e ora intenta desvendar a decadência do processo, ora busca ampliar as vozes que a interpretam e a traduzem.

\footnotetext{
${ }^{9}$ REGO, José Lins do. "Nota à primeira edição". Usina. Rio de janeiro: José Olympio, 13ª ed., 1993. 
É comum a tese de que Fogo morto sintetiza o Ciclo da cana-de-açúcar. Afinal, encontram-se os mesmos elementos, os mesmos conflitos que possibilitaram a José Lins do Rego escrever sobre Carlos de Melo, Ricardo e Tio Juca. Nele, a bagaceira tenta constituirse como ponto de vista, a exemplo do que se vê no diálogo entre Amaro e Laurentino, quase faces de uma mesma moeda. Investigam-se as possibilidades de compreensão do poder, a partir da divergência, na tentativa de contemplar as várias facetas de sua constituição. No topo da pirâmide, o movimento é similar. A comparação de José Paulino com os outros senhores de engenho tem a função de avaliar os contornos do mando na Ribeira. Uma leitura mais atenta revela a ruptura violenta da herança deixada nos primeiros livros de José Lins, como se fosse Fogo morto, antes de tudo, uma profunda reflexão sobre ela. Trata-se de um romance escrito para corrigir o rumo. Liga-se ao Ciclo na rejeição ao modo pelo qual a decadência do Santa Rosa é representada para transformar-se também em sua antítese.

Há, por trás desse encadeamento, uma suspensão temporal e espacial da narrativa frente à busca do narrador pelos velhos tempos, os quais conformariam o espaço da inclusão de Amaro no mundo. As marcas históricas posteriormente acrescentadas ao desenrolar compassado dos acontecimentos lançam o leitor para um campo da indefinição. O passado, o acontecido, circunscreve-se a obra mesma de José Lins do Rego. A acumulação ocorre pela sedimentação das experiências literárias anteriores a Fogo morto. O tempo reitera-se continuamente dentro dos limites da ficção. A consciência do narrador, o seu olhar incisivo e onisciente sobre Amaro, obedece a essa ordenação lógica. O leitor é atraído para um universo hermeticamente fechado em si mesmo, de onde não parece haver saída visível.

Os velhos tempos postos ao lado dos adjetivos atribuídos a mestre Amaro pelo narrador de Fogo morto anunciam e integram a resposta a essa questão. O elemento de que se serve a ação narrativa para ancorar a história do Santa Fé ao Ciclo da cana-de-açúcar é 
José Paulino. O avô de Carlos de Melo será o motivo da dissensão entre Amaro e Laurentino em grau explícito e entre Fogo morto e a obra anterior de José Lins do Rego em adágio cifrado. O diálogo acontece num plano inferior àquele onde se encontra o coronel, realiza-se na bagaceira, na região que circunda a casa-grande. Nela o eito é o destino que une os homens e para onde se dirigem os gritos dos senhores de engenho. A dissensão entre Amaro e Laurentino anuncia a discórdia com o coronel em particular e com o exercício do mando no geral: este como conivente e aquele como reação.

Amaro com sua língua sem arreios não compactua da passividade de Laurentino. O seleiro lança José Paulino na vala comum onde se encontram os outros senhores de engenho da Ribeira porque não os admite como bons. Não lhes reconhece a bondade, seja qual for a sua medida. A suspeita de que o desejo de união entre bondade e grito é o verdadeiro problema da obra do escritor paraibano que vem da constatação de que em nenhum momento consumou-se plenamente tal junção, ainda que por ele perseguida obsessivamente. Em seus romances bondade é sinônimo de autonomia, constitui-se integridade frente à opressão. José Paulino sufoca a bagaceira no grito e na vontade, anula seus pares, não obstante as tentativas de Carlos de Melo de salvaguardar a imagem do avô. O exame feito pelo seleiro é suficiente para desmascarar sua verdadeira face: trata-se de um senhor de engenho igual aos outros. Logo, não é possível atribuir ao Menino de engenho a alcunha de paraíso perdido como fez boa parte da fortuna crítica do autor do Ciclo da canade-açúcar, ao afirmar que o Santa Rosa das primeiras impressões de Carlos de Melo seria a Idade do Ouro dos romances de José Lins do Rego. Tempo que os seus romances posteriores tentaram sem sucesso recuperar. Não se pode reaver aquilo que nunca se teve. Desse impasse nasce o principal conflito da obra de José Lins do Rego. É engano atribuir ao sentimento de inadequação causado ao leitor pela bondade de José Paulino, um caráter fechado em si mesmo. Em Menino de engenho as contradições já são visíveis. A humanidade atribuída por Carlos de Melo a seu avô está longe da real dimensão do 
problema, absorvida pelo leitor na medida em que os livros que precederam Fogo Morto são postos lado a lado. Isso porque cada novo romance parece invalidar o antecessor. Se o leitor não tiver a consciência desse movimento não perceberá por exemplo, o que está realmente em jogo nesse depoimento sobre José Paulino: o velho José Paulino governava os seus engenhos com o coração. Nunca o vi com armas no quarto. Umas carabinas que guardava atrás do guarda-roupa, a gente brincava com elas, de tão imprestáveis. Eu queria um senhor de engenho que protegesse assassinos, que tivesse guarda-costas, gente no rifle. Ouvia falar no dr. Quincas do Engenho Novo, num seu Né do Cipó Branco que com cabras armados arrombara a cadeia para tirar um protegido das grades. Estes sim que eram senhores de engenho de verdade. (...) Mas o velho José Paulino não era homem para tais coisas. Ele era temido mais pela sua bondade. Não havia coragem que levantasse a voz para aquela mansa autoridade de chefe. Não tinha adversários na sua comarca. Os seus inimigos eram mais de sua família do que dele. Herdara-os com o Santa Rosa. ${ }^{10}$

Por contraste direto, percebe-se que José Paulino não é nesse momento um senhor de engenho de verdade. Legítimos proprietários de terra são Quincas do Engenho Novo e Né do Cipó Branco, os quais exercem o poder a exaustão, a ponto de mandar seus homens armados com rifles defender os seus no tribunal, ao passo que José Paulino é pura bondade, jamais comparável ao pé da letra a um senhor de engenho tido como uma farsa. Deduz-se da leitura que ele não pertence ao universo dos canaviais, mas um simples adjetivo para o entendimento do depoimento de Carlos de Melo transforma-se em ruído: ele era temido mais pela sua bondade. Se visto a partir das críticas de Amaro contra o senhor do Santa Rosa temido anunciará os obstáculos futuros ao processo de idealização de José Paulino, que traz em si o germe da suspeita de que as leis do mando também são organizadoras no espaço que abrigou as primeiras impressões do narrador/personagem de Menino de engenho. Em todo o Ciclo da cana-de-açúcar, o desafio de José Lins do Rego será deslocar

\footnotetext{
${ }^{10}$ REGO José Lins do. Menino de engenho. Rio de janeiro: José Olympio, 1995, p. 49. 
o sentimento que anima a imagem do velho patriarca. Nas palavras de Adorno: Ajustandonos a fraqueza dos oprimidos, confirmamos nesta fraqueza o pressuposto da dominação e desenvolvemos nós próprios a medida da grosseria, obtusidade e brutalidade que é necessária para o exercício da dominação. ${ }^{11}$

Em entrevista a Clovis Gusmão, José Lins do Rego oferece ao leitor uma oportunidade para decodificar essa estranha aura de inadequação que envolve a personagem de José Paulino: o velho José Paulino também é de certo modo uma figura real. Tem um pouco do meu avô e muito do que na minha sensibilidade eu desejaria que o meu avô fosse (grifo meu) ${ }^{12}$. Deseja o impossível, um pacto entre o poder que destrói e o massacrado. Tratar-se-ia de uma saída conciliatória, idéia completamente abandonada em Fogo morto como revelam as palavras de Amaro já na primeira página do romance. A experiência brutal da violência realiza-se de modo a reagir contra a idealização de um coronel de engenho, dono de terra e de homens. Creio que hipótese a ser averiguada por mim em pesquisa futura, Capitão Vitorino Carneiro da Cunha é a resolução formal desse impasse. Quando o Papa-rabo se transforma em sopro de humanidade conformado em ação objetiva nos canaviais de José Lins do Rego, o pacto pelas características dessa personagem será entre o sentimento de humanidade e aquela fração dos oprimidos que parece reter em potência, força reativa. Afinal o capitão é o único proprietário de terras em toda a obra de Lins do Rego que não produz e não possui empregado em seu sítio. Soma-se a isso o fato de que em sua casa, filha não há para coagir. Quando o romancista desloca o sentimento que anima José Paulino para Vitorino Carneiro da Cunha, ele se transforma por completo e passa a simbolizar outra e inesperada força de reação contra a violência.

\footnotetext{
11 ADORNO, Theodor. Mínima moralia. São Paulo: Editora Ática, 1993, pp. 29-30.

${ }^{12}$ Idem 
Amaro, Marta e Sinhá: a intimidade como materialização da coerção.

A conversa do seleiro com Laurentino antecede um convite para jantar, e é ao mesmo tempo, a apresentação dos dramas pessoais de Amaro. Quando o diálogo muda das impressões gerais sobre os senhores de engenho para a intimidade simples do seleiro, Amaro assume o lugar de quem manda. E o exame da inversão de papéis revela o processo de reprodução de mecanismos de poder contra os quais, o seleiro já parcialmente se rebelara. Transcorre então, a ação numa espiral centrípeta do mais geral para o mais particular. O recolhimento das atenções à casa do seleiro descortinará o modo perverso da reprodução da violência em todas as instâncias daquele universo. Ao assumir a voz da autoridade, Amaro passa de oprimido a opressor da resistência débil à cumplicidade servil. Isso já acontecera anteriormente no confronto por uma espécie de diferenciação da reação contra o mando: de um lado estará sua mulher Sinhá; de outro sua filha Marta, e sobre elas sempre à espreita, a ira de mestre Amaro impedirá que suas vozes se constituam. Na base daquela organização de poder, abaixo de qualquer trabalhador do eito, as mulheres da bagaceira, última camada de um mundo onde o maior valor é o grito a tudo assistem. Como diz José Lins do Rego: no Brasil a mulher seria quando muito uma geradora de sonetos. Isto, porém até o casamento. Depois marido e mulher viveriam em lados opostos. Os novos sonetos escondidos nos fundos das gavetas com medo da bisbilhotice ciumenta. Marido e mulher como gato e cachorro. Nada da mulher saber dos versos do marido, nada do marido sentir na mulher uma força de criação. E em política e em tudo mais a mulher seria para o marido uma coisa sem maior importância ao seu espírito. Cuidasse ela da casa. E nada mais. "Nada que se aproximasse de inteligente ação extraordinária da mulher através do marido, do filho, do irmão com quem ela colaborasse ou a quem estimulasse 
por meio de uma simpatia docemente criadora". Nunca, diz Gilberto Freyre, numa sociedade aparentemente européia, os homens foram tão sós no seu esforço como os nossos no tempo do Império, tão unilaterais na sua obra política, literária, científica. E continua a ser assim ainda hoje. ${ }^{13}$

Quando se descortinam as relações familiares de Amaro, percebe-se que os gritos não lhe são exclusivos. $\mathrm{O}$ espaço da sua tenda entre a rua que leva aos engenhos e a casa que acolhe Sinhá e Marta espelha em grande medida, as fronteiras que demarcam as relações de poder nos canaviais: no topo da pirâmide, os grandes proprietários; em posição inferior, os trabalhadores "livres"; rente ao chão, suas mulheres que escapam do mando paterno para os gritos de um futuro marido. Um eterno círculo vicioso sem saída nem refúgio, onde o trabalho doméstico em nada diferencia uma das outra, nenhuma escolha a se fazer. Se a moeda de troca que possibilitou ao mestre se descolar, embora não integralmente de seu grupo de origem foi sua força de trabalho. Sinhá e Marta serão diferenciadas por outro valor, isto é, o casamento.

Sinhá representaria o futuro de Marta caso ela tivesse casado. A separação é substancial, ancorando-se no choque inevitável de dois jeitos distintos de compreensão do mando nas cercanias da casa de mestre Amaro. Por isso, o seleiro não compreende a filha. Marta para ele com sua lamúria infindável, não faz qualquer sentido; é um ser a parte, alheio. Quando não consegue vê-la como expressão de uma reação surda contra a violência inerente às relações de poder, ele se aproxima dos senhores de engenho que não perceberam por que ele, seleiro do Santa Fé, desafiou os grandes dos canaviais com sua língua sem arreios.

O rancor do mestre pela falta de um varão para ensinar o ofício, de que tem tanto orgulho, explica-se em grande parte por esse estado de coisas. O filho desejado projeta-se

\footnotetext{
${ }^{13}$ REGO, José Lins. "O Homem e a Mulher”. Dias idos e vividos. Antologia de José Lins do Rego. Seleção, organização e estudo crítico de Ivan Junqueira. Rio de janeiro: Nova Fronteira, 1981, p. 296.

Mediações - Revista de Ciências Sociais, Londrina, v. 10, n.1, p. 87-104, jan.-jun. 2005 ISSN 1414-0543 O GRITO: A REITERAÇÃO DO PODER EM FOGO MORTO DE JOSÉ LINS DO REGO. João Carlos Guedes da Fonseca
} 
ao lado de Marta, com a mesma intensidade de frustração. Se ela se tivesse casado, o movimento natural das águas seguiria curso normal. Ressente-se, portanto, duas vezes a partir da articulação da comparação que tem um mesmo objetivo primário: constatar que os seus desejos não são atendidos, que suas ordens não se propagam. De um lado, Marta continua solteira, contrariando a vontade do seleiro. Fracassa o seu poder que em última análise reflete as leis daquela sociedade. Por paradoxal que seja a ausência de um varão, torna-se também parte de seu malogro.

Tanto Sinhá quanto Amaro é revelado ora pela exposição de seu pensamento íntimo, ora por sua própria voz. O caso de Marta, no entanto, é mais complicado. Embora sejam oferecidas algumas marcas de suas inquietações interiores pelo narrador, o movimento geral é sempre reflexivo, isto é, temos acesso a ela pelas impressões dos outros. Torna-se a materialização de um sujeito sem voz, de uma reação inconsciente contra o mando. Sua vida expõe a violência do grito na raiz. No desenrolar da ação narrativa ela não tem voz constituída porque o mundo ao qual pertence não lhe dá esse direito. São os efeitos de suas lamúrias sobre seus pais que nos servem de material para compor seu personagem.

As observações sobre Marta descortinam uma revolta desesperada contra a hierarquia social. A ação narrativa vai do mais geral com os desaforos do mestre contra José Paulino, ao particular no seio familiar do seleiro, e resvala na base da sociedade organizada pelo grito de mando, ou seja, nas mulheres da bagaceira. O diálogo entre Amaro e Laurentino torna-se disfarce quando o assunto é o drama pessoal do mestre. Embora fale para o pintor, este não responde sequer uma vez. Apenas Sinhá ousa cessar os seus rompantes contra a filha. Não se ouve a voz de Marta, somente dentro de casa sua ladainha sem sentido, sem imagem: para o canto estava a filha Marta de olhos para o chão com medo. $\mathrm{O}$ silêncio e o medo convergem em Marta. Ambos são conseqüências do receio do mestre se revoltar em brados contra a presença incômoda daquela mulher de trinta anos que ainda não se casou. É claro o clima de opressão que a envolve. A impossibilidade do 
matrimônio não é apresentada, não se conhecem as suas causas. No entanto ela se transforma num conflito de grandes dimensões para aquela família.

O ambiente interno de somadas frustrações invade o campo das relações sociais do mestre Amaro: sou pobre seu Laurentino, mas não faço vergonha aos pobres. Está aí minha mulher para dizer. Aqui nesta minha porta tem parado gente rica, gente lorde, para me convidar para isto e aquilo. Não quero nada. Vivo de cheirar sola, nasci nisto e morro nisto. Tenho esta filha que não é um aleijão. O seleiro, que em outro momento se colocava a parte de seu grupo social, os criados, agora tenta alinhavar-se ao tecido comum que veste seus pares. É pobre e não faz vergonha aos pobres, isto é, não deseja ser uma anomalia como nos foi sugerido no levante contra José Paulino. Equilibra-se entre essas duas forças que ora o submetem às leis dos canaviais, ora o sublevam contra as mesmas normas de convívio. Trata-se de uma cisão circunscrita ao espaço simbólico de onde e para onde sua voz se faz ouvida. Subsiste nesse desafogo, uma busca pela manutenção de uma ordem da qual não consegue se desgarrar completamente. Nos limites de sua intimidade, nas cercanias de sua casa, Amaro quer ser igual aos outros. Os convites que recebe dos ricos e a confirmação de que o seu destino não será mudado - cortou, corta e cortará sola para sempre - ratificam o modo peculiar de afirmar sua relação com as leis da bagaceira. No bojo dessa argumentação está Marta. O seu discurso escamoteia o drama familiar. A filha solteira enfrenta o mestre com a mesma voracidade dos gritos de José Paulino, ainda que o faça em sinal invertido e sem consciência. Não é um aleijão, mas não se casou. Sua permanência em casa solteira com a idade avançada marcando a face pálida, contraria as vontades de Amaro. Com sua recusa, Marta finda o poder de mando do seu pai.

É sensível a diferenciação entre o comportamento da mãe e da filha, surda resignação a preencher de compassada ladainha, o choro inexplicável de Marta. Entretanto, a interrupção dos desaforos do mestre na frase seca de Sinhá não se constitui clara oposição contra Amaro. Na verdade, o mestre é extensão dos senhores de engenho na sua casa, que 
por sua vez parece extensão de uma cadeia de sentido mais ampla da qual ninguém parece poder escapar. Não há dessemelhança no modo de reagir ao mando nas duas instâncias. Na rua, espaço aberto, o seleiro não revela a raiz do problema ao desmontar a imagem de José Paulino, enquanto Sinhá não sai dos limites impostos por uma sorte de concisão, inconsciente e desesperada. Sob seu olhar, todos são iguais ante a força do grito. Essa impossibilidade de entender as particularidades de cada uma das mulheres da família o impele as falsas generalizações, como, por exemplo, a de que sua casa seria normal: não se casa porque não quer. É de calibre, como a mãe. O fato é que mãe e filha não se parecem, não são da mesma índole, sequer compartilham das mesmas escolhas. Sinhá se casou com o mestre, Marta continua solteira. E, em outro momento, o narrador revela o instante dessa diferenciação: sabia que a sua mulher se casara com ele porque não encontrara outro. Estava ficando no caritó e aparecera ele com a promessa de casamento. Fingiu que gostava dele para não ficar moça velha como agora ia ficando a filha. Uma moça velha. ${ }^{14}$ De algum modo a escolha de Sinhá corresponde a aceitação das leis que organizam aquele universo. Se agora se rebela contra o marido é conseqüência da tristeza de Marta. A verdadeira dissonância nos canaviais é sua filha. Por isso, Marta é a mais violenta reação contra o mando naquelas veredas, mesmo sem ser escutada, mesmo sem se constituir em discurso. Trata-se de sujeito sem voz, cujo vigor é a revelação crua da opressão a que estava submetida a população do submundo rural da Ribeira. Supõe-se pois, que a recusa de Marta em casar chega a ter efeito significativo no desmonte das relações de poder, superior as críticas do pai e as negativas da mãe.

O narrador respeita a filha de Amaro, não a invade, via discurso indireto livre, não a desautoriza, mas expõe suas contradições. Nela os efeitos da violência são expostos em seu sentido bruto. Os gritos do pai, a surra sem aparente motivo e a ida para o manicômio são revelados como o instantâneo de uma foto eternizada. É assim, será assim e foi assim às

\footnotetext{
${ }^{14}$ Fogo morto. p. 26.

Mediações - Revista de Ciências Sociais, Londrina, v. 10, n.1, p. 87-104, jan.-jun. 2005 ISSN 1414-0543 O GRITO: A REITERAÇÃO DO PODER EM FOGO MORTO DE JOSÉ LINS DO REGO. João Carlos Guedes da Fonseca
} 
margens da Ribeira. Por isso, Marta revela a imobilidade das vozes de baixo, quando se intenta transformar o oprimido em personagem, em sujeito consciente de uma reação contra a opressão. A inflexibilidade de sua posição, contudo, resvala em todos os membros da família: Sinhá, ao contrário do silêncio, ao qual estava destinada irrompe corajosamente os domínios do marido protegendo-a dos desaforos; Amaro que não se conforma com a sorte de ver-se destituído do lugar que ele considera ser seu,por direito, parte para a suicida compensação de enfrentar os senhores de engenho. Porém, nas relações familiares o que mais desconforto lhe causa é a filha, considerada principal responsável por seus desajustes. No mundo onde a bagaceira se subjuga às leis do mando por completo, suas mulheres são elos mais frágeis dessa cadeia do poder. Marta é por isso mais eficaz na revelação das violências dos canaviais do que qualquer outro personagem de Fogo morto.

A ampliação para o universo feminino, entendido como o nível mais baixo daquela hierarquia social, não faz parte dos primeiros romances do Ciclo da cana-de-açúcar. À época, o deslocamento do ponto de vista da casa-grande para o eito privilegiou os homens da bagaceira. Um movimento pendular a oscilar dos senhores de engenho para os trabalhadores. O personagem de mestre Amaro é, em grande medida, resultado da tradição que compreende tanto Ricardo quanto João Miguel, o cabra que acompanhou os últimos dias de Carlos de Melo, em Bangüê. Dialoga diretamente com eles, servindo-se do seu legado para delimitar o seu campo de atuação. No instante em que a força de trabalho se transforma em valor de troca, o seleiro se distancia de seus antepassados com críticas objetivas. Diferencia-se deles, assume-se a exceção. E, nesse sentido, é um personagem novo na obra de José Lins do Rego, uma vez que surge como revelação de comportamento. Entretanto seu fracasso na tentativa de mudar os acontecimentos anuncia íntima paridade com aqueles que o antecederam. Morre Ricardo, morre João Miguel e também Mestre Amaro morrerá, todos representantes de expressões legítimas da impossibilidade de formação de uma voz autônoma na bagaceira. O primeiro foi trabalhar, não obstante sua 
herança para Juca na venda de mantimentos para sua gente. O segundo manteve-se fiel ao senhor de engenho, um cão de guarda a protegê-lo da insolência dos trabalhadores do canavial, a cada dia demonstrando menos o respeito pelo neto de José Paulino. Enfim, Amaro. Embora seja mais forte contra o mando dos grandes proprietários de terra, reproduz contraditoriamente na sua casa, violência idêntica a que outrora condenara. O curioso é o seu comprometimento com a estrutura de poder no canavial, na sua perpetuação, no espaço de sua intimidade. Enquanto estiveram expostos à subserviência, desde o objetivo pacto com Carlos de Melo e com Juca, suas reações às leis do grito se fizeram notar com pouquíssima ou quase nenhuma nitidez. Não é submisso a um personagem apenas, mas a um universo inteiro de onde não consegue fugir.

Última marca da opressão, Marta também não tem voz própria, isto é, capacidade de compreensão do mundo: o narrador mal pode investigar as peculiaridades, as sutilezas de sua individualidade, do grito surdo e mudo, eco da ladainha sem fim, desprovida de sentidos, que ressoa no interior da casa do seleiro.

O caminho percorrido pelo escritor até a publicação de Fogo morto é tortuoso e vai muito além dos canaviais, com faces novas, aparentemente estranhas ao ambiente de seus primeiros romances. É possível alinhavá-los, no entanto, quando a atenção do leitor recai nas nuances e sutilezas internas de sua ficção. Alarga-se o olhar para bem além da casagrande, aqui entendida como expressão máxima do poder, embora permaneça a esperança do encontro de um sujeito reativo a violência do mando, do grito. Contudo, o movimento é interrompido incessantemente por obstáculos intransponíveis de modo que jamais se alcança a formação dessa voz definitivamente perdida no horizonte da sua ficção, a exemplo do que aconteceu com Carlos de Melo, Ricardo, Margarida e Edna; D. Fausta e Antônio Bento. E assim será com Amaro, Sinhá e Marta.

\footnotetext{
Mediações - Revista de Ciências Sociais, Londrina, v. 10, n.1, p. 87-104, jan.-jun. 2005 ISSN 1414-0543 O GRITO: A REITERAÇÃO DO PODER EM FOGO MORTO DE JOSÉ LINS DO REGO. João Carlos Guedes da Fonseca
} 